\section{Application of Response Surface Methodology FOR OPTIMIZATION OF PALM KERNEL SHELL ACTIVATED CARBON PREPARATION FACTORS FOR REMOVAL OF $\mathrm{H}_{2} \mathrm{~S}$ FROM INDUSTRIAL WASTEWATER}

\author{
Omar Abed Habeeba,b, Ramesh Kanthasamya*, Gomaa A. M. \\ Alic,d,e, Rosli Mohd. Yunusa
}

aFaculty of Chemical \& Natural Resources Engineering, Universiti Malaysia Pahang, Gambang, 26300, Kuantan, Malaysia

bNorth Refinery Company, Ministry of Oil of Iraq, Baiji, Salahaldeen, Iraq

cFaculty of Industrial Sciences and Technology, Universiti Malaysia Pahang, Gambang, 26300 Kuantan, Malaysia

dChemistry Department, Faculty of Science, Al-Azhar University, Assiut, 71524, Egypt

eAl-Azhar Center of Nanoscience and Applications (ACNA), Al-Azhar University, Assiut, 71524, Egypt
Article history

Received

11 December 2016

Received in revised form

19 June 2017

Accepted

5 September 2017

*Corresponding author: ramesh@ump.edu.my

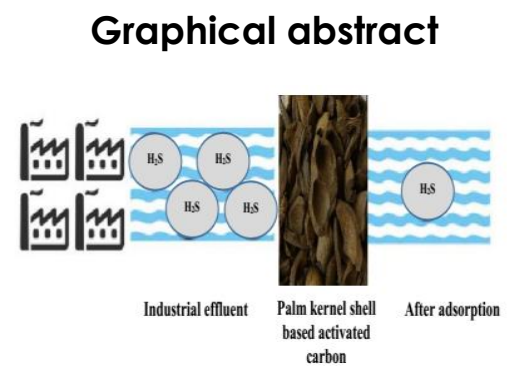

\begin{abstract}
Hydrogen sulfide $\left(\mathrm{H}_{2} \mathrm{~S}\right)$ present in the industrial wastewater can be removed using activated carbon produced from palm kernel shell. In this study, three factors namely activation temperature, impregnation ratio of potassium hydroxide to precursor and activation contact time were investigated for the preparation of activated carbon from palm kernel shell (ACPKS) as an adsorbent toward removal of $\mathrm{H}_{2} \mathrm{~S}$ from synthetic wastewater using central composite design (CCD). Chemical activation method was used to activate the adsorbent with different conditions using $\mathrm{KOH}$ as an activating agent. The batch mode was utilized for studying adsorption process. Two responses (removal efficiency (RE, \%) and yield of adsorbent (Y, \%) are tested by means of two quadratic models. The results shown that the optimum conditions for ACPKS preparation are activation temperature of $829.4{ }^{\circ} \mathrm{C}, \mathrm{KOH}$ to precursor ratio of $3.01 \mathrm{w} \%$ and activation time of 85 min with responses of $94.41 \%$ RE and $39.4 \%$ of ACPKS yield. The study recommended that, ACPKS is the promising adsorbent for removing $\mathrm{H}_{2} \mathrm{~S}$ from wastewater and other aqueous solutions.
\end{abstract}

Keywords: Palm kernel shell, hydrogen sulfide, response surface methodology, statistical analysis

\begin{abstract}
Abstrak
Kehadiran hidrogen sulfida $\left(\mathrm{H}_{2} \mathrm{~S}\right)$ dalam air sisa industri boleh dsingkirkan dengan menggunakan karbon teraktif daripada cangkerang biji sawit. Dalam kajian ini, tiga faktor (suhu pengaktifan, nisbah penghamilan kalium hidroksida $(\mathrm{KOH})$ kepada pelopor dan pengaktifan masa sentuhan) telah diselidik untuk persediaan karbon teraktif daripada cangkerang biji sawit (ACPKS) sebagai penjerap terhadap penyingkiran $\mathrm{H}_{2} \mathrm{~S}$ daripada air sisa sintetik menggunakan reka bentuk komposit tengah (CCD). Kaedah pengaktifan kimia telah digunakan untuk mengaktifkan penjerap dalam pelbagai keadaan yang berbeza menggunakan $\mathrm{KOH}$ sebagai agen
\end{abstract}


pengaktifan. Mod kumpulan telah digunakan untuk mengkaji proses penjerapan. Dua tindak balas (kecekapan penyingkiran (RE, \%) dan hasil bahan penjerap (Y, \%)) telah diuji dengan melaksanakan dua model kuadratik yang berbeza bagi setiap tindak balas. Hasil kajian menunjukkan bahawa keadaan persediaan optimum untuk persediaan ACPKS adalah pada suhu pengaktifan $829.4{ }^{\circ} \mathrm{C}$, nisbah $\mathrm{KOH}$ kepada pelopor $3.01 \mathrm{w} \%$ dan masa pengaktifan 85 minit dengan tindak balas RE sebanyak $94.41 \%$ dan hasil ACPKS sebanyak $39.4 \%$. Kajian ini memperakui bahawa, ACPKS adalah penjerap harapan untuk menghapuskan $\mathrm{H}_{2} \mathrm{~S}$ daripada air sisa dan campuran akueus yang lain.

Kata kunci: Cangkerang biji sawit, hidrogen sulfida, tindak balas metodologi permukaan, analisis statistik

(c) 2017 Penerbit UTM Press. All rights reserved

\subsection{INTRODUCTION}

Hydrogen sulfide $\left(\mathrm{H}_{2} \mathrm{~S}\right)$ is a harmful and putrid compound. It has been broadly delivered as a byproduct in many factories. Excess exposure to $\mathrm{H}_{2} \mathrm{~S}$ might cause both chronic and acute ramifications [1]. As recommended by the Agency for Toxic Substances and Disease (ATSDR) that the minimum inhalation risk level of $\mathrm{H}_{2} \mathrm{~S}$ are $0.02 \mathrm{ppm}$ [2]. However, a concentration of $\mathrm{H}_{2} \mathrm{~S}$ ranged between 500ppm to $1000 \mathrm{ppm}$ lead to human death [3]. Therefore, to safeguard the employees, the Occupational Safety and Health Administration (OSHA) has implemented the limit of exposure 20 ppm for the general industry during the workday. Moreover, studies reported that the main targeted of $\mathrm{H}_{2} \mathrm{~S}$ in human body systems are the kidney and liver [4]. Death can cause by severe exposure to high levels of $\mathrm{H}_{2} \mathrm{~S}$ [5]. On the other hand, the threat of acid rain is an environmental organization issue that caused by $\left(\mathrm{H}_{2} \mathrm{~S}\right)$ through it dissociated by weather humidity and react with oxygen to produce water soluble sulfuric acid (4-6 $\mathrm{g} / \mathrm{L})$ [6]. Moreover, $\mathrm{H}_{2} \mathrm{~S}$ has economic problem arising from corrosion of metals as well as safety problem posed by its highly flammable nature (even in the low level of $\mathrm{H}_{2} \mathrm{~S}$ ) [7]. Another negative impact, $\mathrm{H}_{2} \mathrm{~S}$ is one of the main poisons for many industry catalysts, and in addition it is a destructive gas towards pipelines and equipment [8]. So removal of $\mathrm{H}_{2} \mathrm{~S}$ is necessary because of it is exceptionally hazardous and sway the security, environment and human wellbeing. It is essential to find a suitable technique to deal with ousting $\mathrm{H}_{2} \mathrm{~S}$ from wastewater before transfer it out to the water bodies turn into the ecological controls concern. The removal of $\mathrm{H}_{2} \mathrm{~S}$ has been carried out by many methods like magnesium peroxide $\left(\mathrm{MgO}_{2}\right)[9]$. $\mathrm{Fe}^{2+}$ and $\mathrm{Fe}^{3+}$ ions [10], biofilters [11], electrochemical processes [12] and adsorption [13]. However, the adsorption processes are still widely acceptable among researchers [14]. This is because of adsorption method has advantage of low initial cost, ease of operation, simplicity of design, biodegradability, high efficiency and complete removal of pollutants even from dilute solutions and insensitivity to toxic substances [15-20]. In the past, purification technology by adsorption process using activated carbon has been exceedingly used in water purification production of industrial gases and petrochemical industries [21]. Researchers have been investigated the removal of $\mathrm{H}_{2} \mathrm{~S}$ by many kinds of adsorbent materials such as zeolite[22], silica [23], alumina [24], and activated carbon [25]. Compared to other adsorbents, activated carbon has more widely used as an adsorbent due to it has the acceptable surface area, porosity and even various functional oxygenated groups. But adsorption operation by using the commercially activated carbon to purify water is not cost effective [26-27]. Therefore, many agricultural wastes rich in lignin and cellulose containing structures such as aldehydes, ketones and alcohols are good adsorbents [28]. Many researchers have studied various low-cost bio adsorbents (agricultural wastes, which are environmentally friendly) such as palm oil shell [29] and different agricultural/forestry wastes [30]. Recently, the cost becomes an important issue among researchers. Low cost activated carbon obtained from carbonaceous wastes become attractive in term of cost and availability and it can be considered as an effective method to remove pollutants from water and air by adsorption. Therefore, the wonderful future of activated carbons creates them very appealing for purification of water [31], gases [32]. Low-cost adsorbent preparation from waste agricultural materials has dual benefits of being economical and environmental friendly process [33]. AC from agricultural wastes have been used in several studies such as palm oil shell [29], nut shell [21], pomelo skin [31], and coffee industry waste [32]. Malaysia is currently the world's largest producer and exporter of palm oil. Therefore, huge amount of wastes are produces from palm oil mill [34]. Palm kernel shell is one of the important biomass materials The AC from palm kernel shell is subjected to either chemical activation or physical activation method. In this study, chemical activation using $\mathrm{KOH}$ is employed for preparing high-adsorption-capacity activated carbon from palm kernel shell using Response Surface Method (RSM). RSM is a helpful statistical model apparatus which empowers 
cognizance of ideal variables to get the optimum preparation conditions to prepare suitable activated carbon for removal of $\mathrm{H}_{2} \mathrm{~S}$. This method was proposed by Box and Wilson [35] and it could be utilized to investigate the effect of factors and the interactions onto responses [36]. The main objective of this work is to investigate the optimum conditions needed for the preparation of ACPKS to maximize the removal efficiency (RE, \%) and yield of activated carbon ( $Y$, \%) to remove dissolved $\mathrm{H}_{2} \mathrm{~S}$ from synthetic petroleum wastewater.

\subsection{METHODOLOGY}

\subsection{Raw Material}

Palm kernel shell (PKS) waste residue was gotten from United Palm Oil Mill, Nibong Tebal, Malaysia. Firstly, the PKS was washed and dried to remove water. This was followed by mechanical grinding and sieving to get particle sizes of $0.5-1 \mathrm{~mm}$ and further drying at $110^{\circ} \mathrm{C}$ for $24 \mathrm{~h}$ until constant weight was obtained. Then, the precursor of PKS was soaked with $\mathrm{KOH}$ for $24 \mathrm{~h}$, with the $\mathrm{KOH} /$ precursor mass ratios of $2: 1-4: 1$.

\subsection{Preparation of Activated Carbon}

The carbonization process was conducted by using the tubular horizontal furnace. The dried sample subjected to a pyrolysis process between $724-1000^{\circ} \mathrm{C}$ for a known period with a heating rate of $10^{\circ} \mathrm{C} / \mathrm{min}$ in an inert atmosphere ( $\mathrm{N}_{2}$ flow of $\left.150 \mathrm{~mL} / \mathrm{min}\right)$ for activated carbon production. The activation process of carbon was implemented depended on the suggestion of software. The three parameters investigated were Activation temperatures, amount of $\mathrm{KOH}$ to precursor and activation contact time. The ranges were $724-1000{ }^{\circ} \mathrm{C}, 2: 1-4: 1$ and 60-120 min, respectively which demonstrated in Table 1 . The final activated carbon product was labeled as ACPKS. Moreover, the preparation of synthetic wastewater was set up as per the strategy reported by somewhere else[37].

\subsection{Modeling and Optimization}

\subsubsection{Design of Experiment}

Response surface methodology is an accumulation of numerical and statistical techniques that are valuable for demonstrating, investigation, analysis and modeling of problems in which a response is affected by a few factors [38]. In the current study, the three preparation factors are implemented based on development quadratic models for responses such as RE (\%) and $Y(\%)$, as well as investigated the optimum preparation conditions. Central Composite Design (CCD) is a useful tool to study the activation process. It is conducted for fitting a quadratic surface. This tool used to analyze the interaction effect between those parameters, as well as to optimize the effective parameters with a minimum number of experiments. In general, the CCD consists of a $2 k$ factorial runs with $2 k$ axial or star runs and center runs $\mathrm{n}_{c}$ [38]. The three parameters investigated were Activation temperatures $(T)$, the percentage of $\mathrm{KOH}$ to precursor and activation contact time ( $t$ ) with ranges of $724-1000{ }^{\circ} \mathrm{C}, 2-4$ and 60-120 min, respectively. The responses were RE (\%) and $Y(\%)$ as seen in Table 1. At the center point were performed six replications. Thus, the suggested required experimental $(\mathrm{N})$ by software is as bellow:

$N=2 k+2 k+n_{c}=23+2 * 3+6=20$

The residual error was estimated by replicating the central point. According to the range of each factor, the independent factors are coded to the $(-1,1)$ interval. The low and high levels are coded -1 and +1 , respectively. The axial points are located at $( \pm \infty, 0,0)$, $(0, \pm \infty, 0),(0,0, \pm \infty)$ where $œ$ is the distance of the axial point from the center and makes the design rotatable.

In the current study, the preparation conditions for preparing (ACPKS) by utilizing the CCD. The factors tested were (i) $\mathrm{xl}$, activation temperature $(\mathrm{C})$; (ii) $\times 2, \mathrm{KOH}$ to precursor and (iii) $x 3$, activation contact time. The outcomes acquired and all design informations of the tests did are appeared in Table 1. To minimize the impacts of the uncontrolled components, the all the tests sequence was randomized. The two responses were RE (\%) and $Y$ (\%). The responses were utilized to build up an empirical model which correlated the response to the three preparation factors utilizing a second degree polynomial equation as given by Eq. (2) [39]:

$$
Y=b_{0}+\sum_{i=1}^{n} b_{i} x_{i}+\left(\sum_{i=1}^{n} b_{i i} z_{i}\right)+\sum_{i=1}^{n-1} \sum_{j=i+1}^{n} b_{i j} x_{i} x_{j}
$$

where $Y$ is the predicted response, $b_{0}$ the constant coefficient, bi the linear coefficients, bij the interaction coefficients, bii the quadratic coefficients and $x i, x j$ are the coded values of the activated carbon preparation variables.

\subsubsection{Graphical Analysis and Statistical}

The statistical tools such as coefficient of determination ( $R$-squared), probability ( $P$ value), residual and Fisher value ( $F$-value) are considered the indicators of showing significance of the model equations [40 - 41]. However, 3D plot graphs are utilized to investigate the interaction impact of variables on responses.

\subsubsection{Optimization and Validation}

Optimization strategy was utilized to investigate the optimum preparation conditions for the procedure factors under consideration. To accomplish this, objectives are designed the matrix table for all the 
variables in ranges with limitations $724-1000{ }^{\circ} \mathrm{C}$, 2-4 and 60-120 min for factors activation temperatures, percentage of $\mathrm{KOH}$ to precursor and activation time, respectively. For the responses surface, the objective for RE (\%) and Y (\%) were set "maximize". Subsequently adsorption capacity becomes the objective function or performance index. Moreover, model validation was carried out by conducting batch test under optimum preparation conditions. To evaluate the validity of the model, the model predicted values got compared with experimental values.

Table 1 Three factors central composite design matrix and the values of the responses function

\begin{tabular}{|c|c|c|c|c|c|c|c|c|}
\hline \multirow[t]{2}{*}{ Run } & \multicolumn{6}{|c|}{ ACPKS preparation condition variables } & \multirow[t]{2}{*}{ RE (\%) } & \multirow[t]{2}{*}{ Yield (\%) } \\
\hline & \multicolumn{3}{|c|}{ Coded variables } & $\begin{array}{l}\text { A: Activation } \\
\text { temperature } \\
\text { (C) }\end{array}$ & $\begin{array}{l}\text { B: KOH to } \\
\text { precursor } \\
\text { ratio }\end{array}$ & $\begin{array}{c}\text { C: Activation } \\
\text { contact time } \\
\text { (min) }\end{array}$ & & \\
\hline 1 & -1.000 & $\begin{array}{l}-1.000 \\
\end{array}$ & -1.000 & 724.00 & 2.00 & 60.00 & 86.3 & 40.5 \\
\hline 2 & -1.000 & -1.000 & -1.000 & 724.00 & 2.00 & 60.00 & 85.9 & 41 \\
\hline 3 & 1.000 & -1.000 & -1.000 & 1000.00 & 2.00 & 60.00 & 85.5 & 35 \\
\hline 4 & 1.000 & -1.000 & -1.000 & 1000.00 & 2.00 & 60.00 & 85.8 & 35.6 \\
\hline 5 & -1.000 & 1.000 & -1.000 & 724.00 & 4.00 & 60.00 & 87 & 39 \\
\hline 6 & -1.000 & 1.000 & -1.000 & 724.00 & 4.00 & 60.00 & 86.7 & 38.7 \\
\hline 7 & 1.000 & 1.000 & -1.000 & 1000.00 & 4.00 & 60.00 & 87.7 & 32.9 \\
\hline 8 & 1.000 & 1.000 & -1.000 & 1000.00 & 4.00 & 60.00 & 87.5 & 33 \\
\hline 9 & -1.000 & -1.000 & 1.000 & 724.00 & 2.00 & 120.00 & 86 & 38.1 \\
\hline 10 & -1.000 & -1.000 & 1.000 & 724.00 & 2.00 & 120.00 & 86.4 & 38 \\
\hline 11 & 1.000 & -1.000 & 1.000 & 1000.00 & 2.00 & 120.00 & 86.5 & 32 \\
\hline 12 & 1.000 & -1.000 & 1.000 & 1000.00 & 2.00 & 120.00 & 86.4 & 31.9 \\
\hline 13 & -1.000 & 1.000 & 1.000 & 724.00 & 4.00 & 120.00 & 86 & 38.2 \\
\hline 14 & -1.000 & 1.000 & 1.000 & 724.00 & 4.00 & 120.00 & 86.4 & 38 \\
\hline 15 & 1.000 & 1.000 & 1.000 & 1000.00 & 4.00 & 120.00 & 87.7 & 31.3 \\
\hline 16 & 1.000 & 1.000 & 1.000 & 1000.00 & 4.00 & 120.00 & 88 & 31 \\
\hline 17 & -1.682 & 0.000 & 0.000 & 629.91 & 3.00 & 90.00 & 84.5 & 39 \\
\hline 18 & -1.682 & 0.000 & 0.000 & 629.91 & 3.00 & 90.00 & 84.6 & 39.2 \\
\hline 19 & 1.682 & 0.000 & 0.000 & 1094.09 & 3.00 & 90.00 & 86 & 27.5 \\
\hline 20 & 1.682 & 0.000 & 0.000 & 1094.09 & 3.00 & 90.00 & 86 & 27.6 \\
\hline 21 & 0.000 & -1.682 & 0.000 & 862.00 & 1.32 & 90.00 & 87.4 & 38.4 \\
\hline 22 & 0.000 & -1.682 & 0.000 & 862.00 & 1.32 & 90.00 & 87.3 & 38.5 \\
\hline 23 & 0.000 & 1.682 & 0.000 & 862.00 & 4.68 & 90.00 & 90 & 36.4 \\
\hline 24 & 0.000 & 1.682 & 0.000 & 862.00 & 4.68 & 90.00 & 90.2 & 36.6 \\
\hline 25 & 0.000 & 0.000 & -1.682 & 862.00 & 3.00 & 39.55 & 87 & 39.8 \\
\hline 26 & 0.000 & 0.000 & -1.682 & 862.00 & 3.00 & 39.55 & 87.3 & 39.5 \\
\hline 27 & 0.000 & 0.000 & 1.682 & 862.00 & 3.00 & 140.45 & 87 & 36.5 \\
\hline 28 & 0.000 & 0.000 & 1.682 & 862.00 & 3.00 & 140.45 & 87.2 & 36.5 \\
\hline 29 & 0.000 & 0.000 & 0.000 & 862.00 & 3.00 & 90.00 & 95 & 38.5 \\
\hline 30 & 0.000 & 0.000 & 0.000 & 862.00 & 3.00 & 90.00 & 94.5 & 38.6 \\
\hline 31 & 0.000 & 0.000 & 0.000 & 862.00 & 3.00 & 90.00 & 94.6 & 38 \\
\hline 32 & 0.000 & 0.000 & 0.000 & 862.00 & 3.00 & 90.00 & 95.3 & 39.6 \\
\hline 33 & 0.000 & 0.000 & 0.000 & 862.00 & 3.00 & 90.00 & 94 & 38.3 \\
\hline 34 & 0.000 & 0.000 & 0.000 & 862.00 & 3.00 & 90.00 & 95 & 38.7 \\
\hline
\end{tabular}




\subsection{RESULTS AND DISCUSSION}

\subsection{CCD Model Analysis and Results}

At the beginning of the process of looking optimum conditions is to distinguish the info factors that have the most prominent impact on the experimental responses. Activation temperature (724-1000 $\left.{ }^{\circ} \mathrm{C}\right)$, activation mass ratio $\mathrm{KOH}$ : Precursor (w\%), and activation contact time (60-120 min) are the parameters with responses of RE (\%) and $Y(\%)$. A mathematical relationship between the responses and the preparation process factors was developing by software to get a polynomial model. A quadratic polynomial model was suggested by software to develop the relationship between factors and responses. The predicted and experimental values for both responses and coded, uncoded preparation factors corresponding to different combinations of selected factors are showed in Table 2 and 3.

In addition, Correlation between the factors and responses surface were improved utilizing CCD. As indicated by the consecutive model sum of squares, the models were chosen in light of the most astounding request polynomials where the additional terms were the models were not aliased and significant [42]. Correlation coefficient and standard deviation were utilized to rectify the fitness of the developed models. The closer the $R^{2}$ value is to unity and the, smaller the standard deviation the preferable the model in predicting the response [43]. Table 2 demonstrates that the quadratic model for RE \% response which has generally a moderately high $R^{2}$ value of 0.9932 with adjusted $R^{2}(0.9907)$ in reasonable agreement with predicted $R^{2}$ (0.9875) and small standard deviation of 0.32 . It was additionally seen on the table that the quadratic model for response RE was not aliased. This suggests that the quadratic model can be utilized to portray the relationship between the interacting factors and response. Table 3 likewise demonstrates that the quadratic model for $Y$ (\%) which has generally a moderately high $R^{2}$ value of 0.9913 with adjusted $R^{2}$ $(0.9881)$ in reasonable agreement with predicted $R^{2}$ (0.9838) and small standard deviation of 0.39 and the quadratic model for response $Y$ was not aliased. The relationship between the interacting factors and response $Y$ could be described by implementing the quadratic model.

Table 2 Regression statistics for removal efficiency (RE, \%) at equilibrium

\begin{tabular}{llllll}
\hline Source & $\begin{array}{l}\text { Standard } \\
\text { deviation }\end{array}$ & $\mathbf{R}^{\mathbf{2}}$ & $\begin{array}{l}\text { Adjusted } \\
\mathbf{R}^{\mathbf{2}}\end{array}$ & $\begin{array}{l}\text { Predicted } \\
\mathbf{R}^{2}\end{array}$ & Comment \\
\hline Linear & 3.37 & 0.0403 & -0.0557 & -0.0847 & \\
$2 \mathrm{FI}$ & 3.54 & 0.0480 & -0.1636 & -0.1728 & \\
$\underline{\text { Quadratic }}$ & $\underline{\mathbf{0 . 3 2}}$ & $\underline{\mathbf{0 . 9 9 3 2}}$ & $\underline{\mathbf{0 . 9 9 0 7}}$ & $\underline{\mathbf{0 . 9 8 7 5}}$ & $\underline{\text { Suggested }}$ \\
Cubic & 0.28 & 0.9956 & 0.9927 & 0.9906 & Aliased \\
\hline
\end{tabular}

Table 3 Regression statistics for adsorbent activated carbon yield (Y, \%) at equilibrium

\begin{tabular}{llllll}
\hline Source & $\begin{array}{l}\text { Standard } \\
\text { deviation }\end{array}$ & $\mathbf{R}^{\mathbf{2}}$ & $\begin{array}{l}\text { Adjusted } \\
\mathbf{R}^{\mathbf{2}}\end{array}$ & $\begin{array}{l}\text { Predicted } \\
\mathbf{R}^{\mathbf{2}}\end{array}$ & Comment \\
\hline Linear & 1.77 & 0.7722 & 0.7494 & 0.7146 & \\
$2 \mathrm{FI}$ & 1.83 & 0.7824 & 0.7340 & 0.7135 & \\
$\underline{\text { Quadratic }}$ & $\underline{\mathbf{0 . 3 9}}$ & $\underline{\mathbf{0 . 9 9 1 3}}$ & $\underline{\mathbf{0 . 9 8 8 1}}$ & $\underline{\mathbf{0 . 9 8 3 8}}$ & $\underline{\text { Suggested }}$ \\
Cubic & 0.35 & 0.9941 & 0.9903 & 0.9867 & Aliased \\
\hline
\end{tabular}

\subsection{Development of Regression Model Equation}

The correlation between the response surface and factors was developed by using CCD. Moreover, the wellness of the models developed could be explained by the standard deviation and Relationship coefficient [42], [44]. Thus, the $R^{2}$ values of 0.9932 and 0.9913 estimated that $99.32 \%$ and $99.13 \%$ of the difference in RE (\%) and $Y(\%)$ could be attributed to the three factors (A -activation temperature, B- $\mathrm{KOH}$ : Precursor activation ratio, Cactivation contact time. Therefore, the the quadratic model suggested by the software can be written as $[37,44]$ :

Removal efficiency (RE, \%)

$R E=94.7+0.34 A+0.64 B+0.03 C+0.33 A B+0.2 A C-0.16 B C-$ $3.34 A^{2}-1.12 B^{2}-2.68 C^{2}$

Adsorbent activated carbon yield (Y, \%)

$Y=38.63-3.21 A-0.16 B-1.02 C+0.16 A B-0.21 A C+0.44 B C-$ $1.93 A^{2}-0.46 B^{2}-0.25 C^{2}$

\subsection{Statistical Analysis}

The lack-of-fit test for response surface quadratic model for RE (\%) and the analysis of variance (ANOVA) are shown in Table 4. From Table 4 can be observed the values of F-value of (391.86) and Pvalue less than (0.05) which indicated that the quadratic model is significant [41]. From that, could be concluded the significant of others parameters and interactions between them. So, can be seen from Table 4 that $A, B, A B, B C, A C, A^{2}, B^{2}$ and $C^{2}$ are significant, while only $C$ is the insignificant model terms.

Table 5 represents the lack-of-fit test for a response surface quadratic model for $Y(\%)$ and analysis of variance (ANOVA) values. It shows that the significant of the models for parameters and interaction between parameters. From the $F$-value of (304.60), and $P$ value less than 0.0001 can be indicated that the quadratic model is significant [45]. So, from Table 5 can be seen that $A B$ is the insignificant model terms. While the others such as $A$, $B, C, A C, B C, A^{2}, B^{2}$, and $C^{2}$, are significant. 
Ramesh Kanthasamy et al. / Jurnal Teknologi (Sciences \& Engineering) 79:7 (2017) 1-10

Table 4 Analysis of variance (ANOVA) and lack-of-fit test for response surface quadratic model for RE (\%)

\begin{tabular}{|c|c|c|c|c|c|c|}
\hline Sources & $\begin{array}{l}\text { Sum of } \\
\text { squares }\end{array}$ & df & $\begin{array}{l}\text { Mean } \\
\text { square }\end{array}$ & F-value & P value & Comment \\
\hline Model & 353.44 & 9 & 39.27 & 391.86 & $<0.0001$ & significant \\
\hline A-Activation temperature & 3.15 & 1 & 3.15 & 31.44 & $<0.0001$ & significant \\
\hline B-KOH:Carbon ratio & 11.15 & 1 & 11.15 & 111.24 & $<0.0001$ & significant \\
\hline C-Activation contact time & 0.025 & 1 & 0.025 & 0.25 & 0.6197 & insignificant \\
\hline$A B$ & 1.69 & 1 & 1.69 & 16.86 & 0.0004 & significant \\
\hline$A C$ & 0.64 & 1 & 0.64 & 6.39 & 0.0185 & significant \\
\hline$B C$ & 0.42 & 1 & 0.42 & 4.22 & 0.0511 & significant \\
\hline$A^{2}$ & 250.88 & 1 & 250.88 & 2503.34 & $<0.0001$ & significant \\
\hline $\mathrm{B}^{2}$ & 100.95 & 1 & 100.95 & 1007.29 & $<0.0001$ & significant \\
\hline$C^{2}$ & 162.14 & 1 & 162.14 & 1617.87 & $<0.0001$ & significant \\
\hline Residual & 2.41 & 24 & 0.10 & & & \\
\hline Lack of Fit & 0.84 & 5 & 0.17 & 2.03 & 0.1205 & not significant \\
\hline
\end{tabular}

Table 5 Analysis of variance (ANOVA) and lack-of-fit test for response surface quadratic model for adsorbent activated carbon yield $(Y, \%$.)

\begin{tabular}{lcccccc}
\hline Sources & $\begin{array}{c}\text { Sum of } \\
\text { squares }\end{array}$ & df & $\begin{array}{c}\text { Mean } \\
\text { square }\end{array}$ & F-value & P value & Comment \\
\hline Model & 410.28 & 9 & 45.59 & 304.60 & $<0.0001$ & significant \\
A-Activation temperature & 281.27 & 1 & 281.27 & 1879.36 & $<0.0001$ & significant \\
B-KOH:Carbon ratio & 10.04 & 1 & 10.04 & 67.08 & $<0.0001$ & significant \\
C-Activation contact time & 28.29 & 1 & 28.29 & 189.00 & $<0.0001$ & significant \\
AB & 0.42 & 1 & 0.42 & 2.82 & 0.1059 & insignificant \\
AC & 0.72 & 1 & 0.72 & 4.83 & 0.0379 & significant \\
BC & 3.06 & 1 & 3.06 & 20.46 & 0.0001 & significant \\
A 2 & 83.92 & 1 & 83.92 & 560.76 & $<0.0001$ & significant \\
B2 & 4.81 & 1 & 4.81 & 32.16 & $<0.0001$ & significant \\
C2 & 1.41 & 1 & 1.41 & 9.41 & 0.0053 & significant \\
Residual & 3.59 & 24 & 0.15 & & & significant \\
Lack of Fit & 1.60 & 5 & 0.32 & 3.05 & 0.0347 & \\
\hline
\end{tabular}


Figure $1 \mathrm{a}$ and $\mathrm{b}$ demonstrates the plots of actual versus predicted values of response RE (\%) and the $Y$ (\%) values which shows the predicted values are quite close to the experimental values, showing that the successful of the developed model. In addition, the interaction of the three factors is described very well by these response surface model equations.
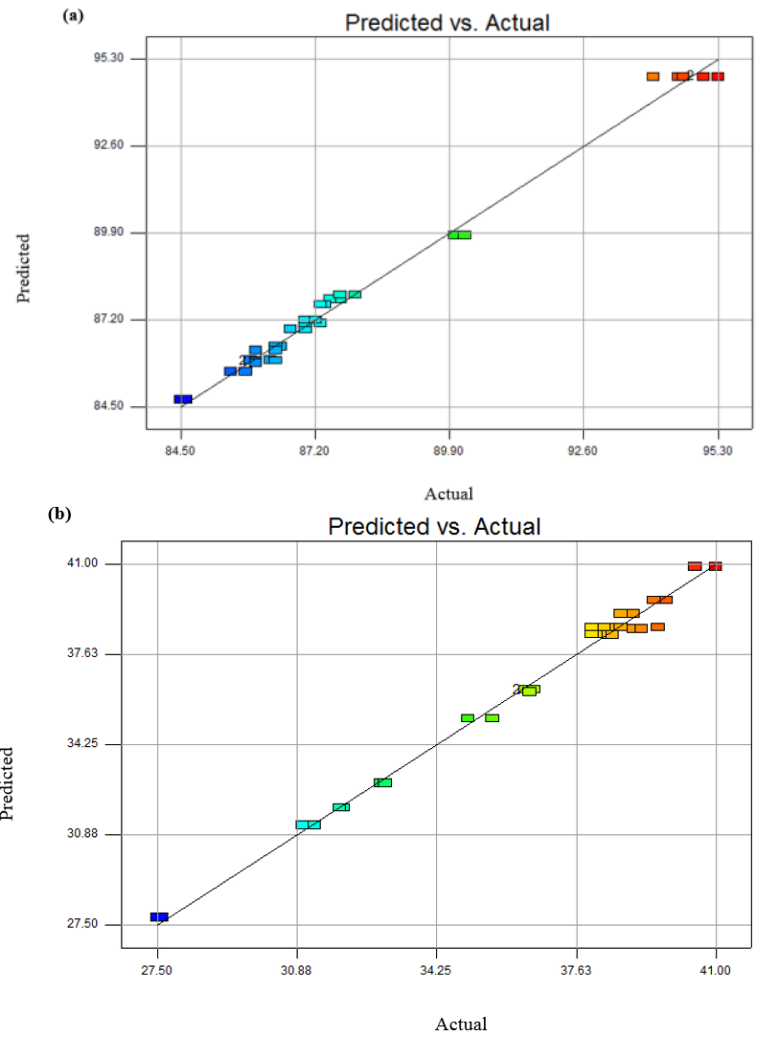

Figure 1 actual and predicted curve for RE (\%) (a) and activated carbon yield ( $Y, \%)(b)$

\subsection{The Interaction Impact of Factors on Response of Removal Efficiency (RE, \%)}

The 3D graph of the interaction impact of factors such as activation temperature and $\mathrm{KOH}$ : Precursor ratio at constant of activation contact time on response $R$ is clearly demonstrated in Figure 2. It shows the clear interactions between these two parameters. The activation temperature with a range between 724 to $1000{ }^{\circ} \mathrm{C}$ and activation agent mass ratio ( $\mathrm{KOH}$ : Precursor) with range of (2-4 w\%). From Figure 2 it could be noticed that the activation temperature has significant impact on the RE (\%) value. At the activation temperature $\left(724{ }^{\circ} \mathrm{C}\right)$ the effect was very low and it has minimum value of RE \% which is around $85.9 \%$. After that, the RE\% start increased with increasing the activation temperature until reach the optimum requirement of activation temperature for getting the optimum RE\% which around of $829.4{ }^{\circ} \mathrm{C}$ with RE of $94.41 \%$. After that, rising the activation temperature affected the RE \%. This is because of because of the rising activation temperature lead to decreasing the surface area of the adsorbent and increase the average pore size. Moreover, the higher temperature causes to evaporate the element of potassium $(K)$ due to the boiling point of potassium is $780^{\circ} \mathrm{C}$. Thus, the number of active sites will be decreased and the percentage of acid/base reaction decreases. Hence, the removal percentage of $\mathrm{H}_{2} \mathrm{~S}$ is decreasing with increased the activation temperature [46]. Moreover, the activation agent also has important effect on the response RE\%. As could be seen from Figure 2 as low the $\mathrm{KOH}$ to precursor as low the RE\% then the percentage of RE increased when IR increased that mean the chemical activation attributed more on the RE\% same trend observed on previous work [47, 48].

More so, the 3D graphs of interaction impact of activation contact time and the activation temperature of $\mathrm{AC}$ at constant $\mathrm{KOH}$ to precursor on the response of RE (\%) are shown in Figure 3. The interaction of activation contact time range (60-120 $\mathrm{min}$ ) and activation temperature on AC range (724$1000^{\circ} \mathrm{C}$ ) have a significant effect on response RE (\%). From Figure 3 at the lower values of factors, it is observed that both factors have significant impact on the RE \% process at the beginning. However, the effect of the factors increased with increasing activated temperature and activation time until reach the optimum contact time and temperature that required to improve the RE (\%) which is around 85 min and $829.4{ }^{\circ} \mathrm{C}$ respectively. Moreover, both of factors have almost same impact on the response RE $\%$ (see Figure 3).

Furthermore, Figure 4 representes the 3D graph of the interaction between activation contact time and $\mathrm{KOH}$ to precursor at constant of activation temperature of AC on response RE (\%). From Figure 4 it could be noticed that activation contact time has relatively comparable impact with $\mathrm{KOH}$ to precursor on response RE\%. However, the $\mathrm{KOH}$ to precursor has more impact on the RE\% as seen in Figure 4. It can be seen from Figure 4 that both of factors have very low RE (\%) at (60 $\min \& 2 \mathrm{w} \%$ ) which is the lower factors values. Thus, the RE (\%) start increasing when the factors value increasing until the optimum values that the RE (\%) has the higher amount. The activation agent has a specific required time to develop the porosity and burn all the materials that can affect the developed porosity and adsorption capacity of the adsorbent. Similar observation reported by Li, S. et al. [46]. 


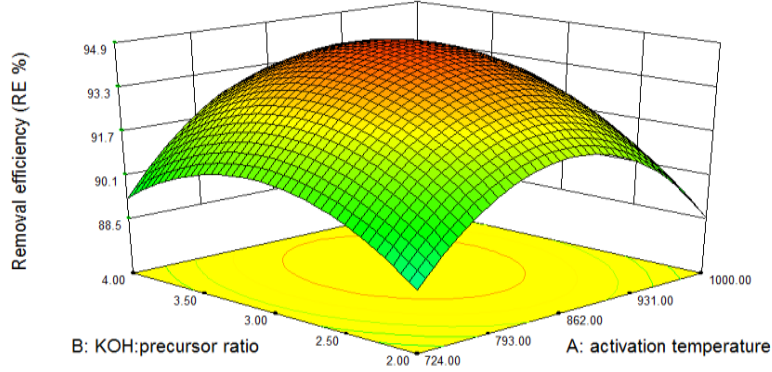

Figure 2 Interaction impact of activation temperature and $\mathrm{KOH}$ to precursor ratio at constant activation contact time on response RE $(\%)$

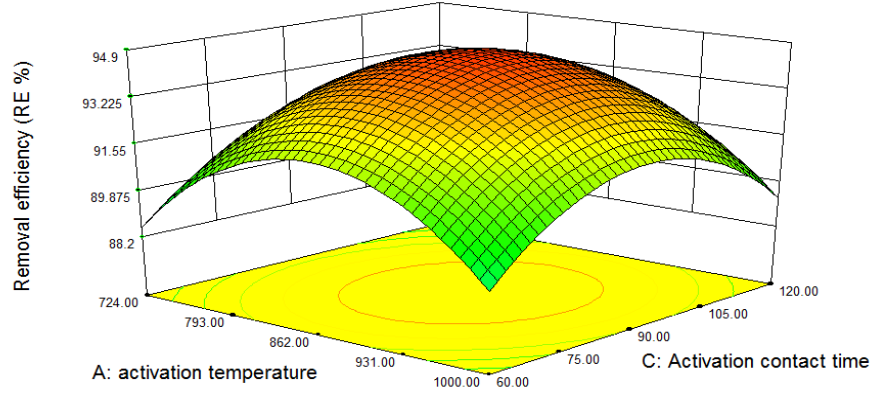

Figure 3 Interaction impact of activation contact time and the activation temperature at constant $\mathrm{KOH}$ to precursor ratio on the response of RE (\%)

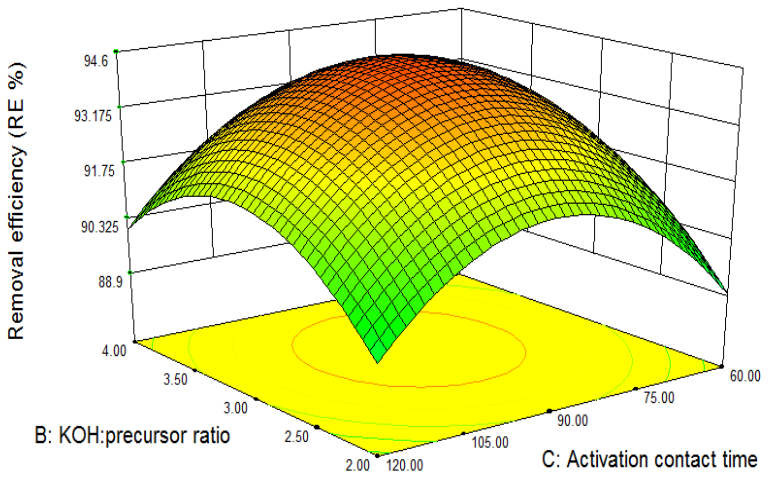

Figure 4 Interaction impact of activation contact time and $\mathrm{KOH}$ : precursor ratio at constant activation temperature on response RE (\%)

\subsection{The Interaction Impact of Factors on Response of Activated Carbon Yield (Y, \%)}

Figure 5 demonstrated the 3D graph of interaction impact between the $\mathrm{KOH}$ : Precursor ratio and the activation temperature of $A C$ on $Y(\%)$ at constant of activation contact time. It could be seen from the 3D graph that the factors of activation temperature on AC have the most impact on the response $Y(\%)$ compared with the $\mathrm{KOH}$ : Precursor ratio factors. The maximum product of $\mathrm{AC}$ yield found in the activation temperature around $724^{\circ} \mathrm{C}$. While the effect of factor of $\mathrm{KOH}$ : Precursor ratio was quite smaller (see Figure $5)$.
In addition, Figure 6 demonstrated the 3D graph of interaction between activation contact time and the activation temperature of $A C$ on $Y(\%)$ at constant $\mathrm{KOH}$ : Precursor ratio. From Figure 6 it is noticed that the activation temperature of $A C$ has a significant effect on yield (\%). So, from Figure 6 could be seen that the optimum activation temperature required for optimum yield around $724{ }^{\circ} \mathrm{C}$ as demonstrated in Figure 6 . On the other hand, during the process as can notice that the impact of factor contact time on response yield was low. Thus, as the contact time value decreased the yield (\%) start increased until reach the optimum contact time required to get optimum yield (\%) which is around 60 (min).

Finally, the 3D graph of the interaction of activation contact time and $\mathrm{KOH}$ : Precursor on $\mathrm{AC}$ yield (\%) at a constant activation temperature of $A C$ is shown in Figure 7. From that, it noticed that both activation contact time and $\mathrm{KOH}$ : Precursor ratio have almost a significant impact on AC yield (\%). Both of factors have a very low yield at (120 min \& 4 w\%) which is the higher factors values. Thus, the AC yield (\%) began increasing when the factors values decreasing until reaching the optimum values $Y(\%)$.

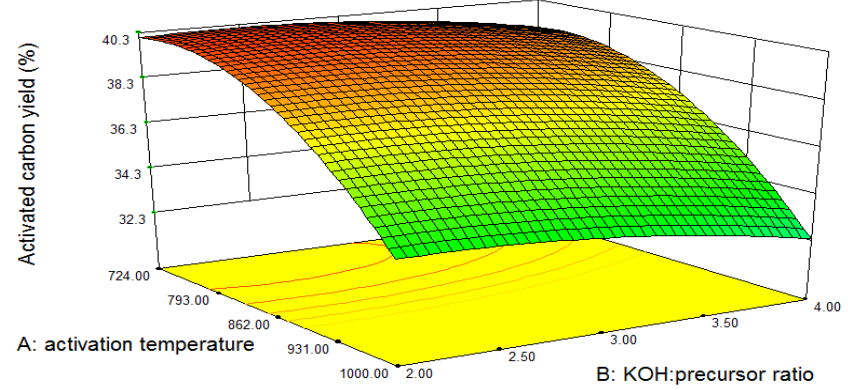

Figure 5 Interaction impact of $\mathrm{KOH}$ to precursor ratio and the activation temperature on $Y(\%)$ at constant activation contact time

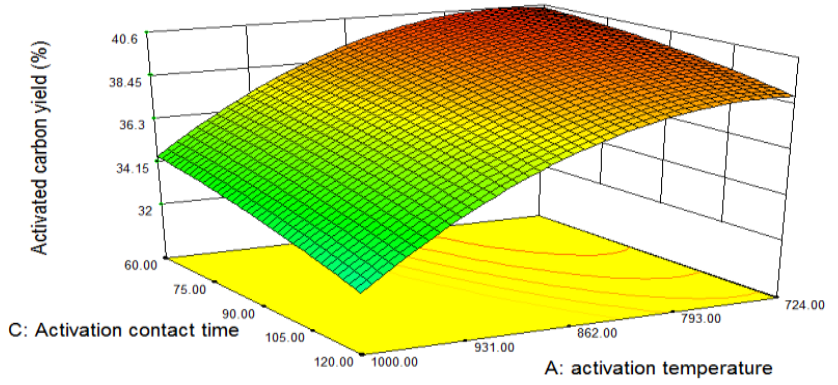

Figure 6 Interaction impact of activation contact time and the activation temperature on $\mathrm{Y}(\%)$ at constant $\mathrm{KOH}$ to precursor ratio 


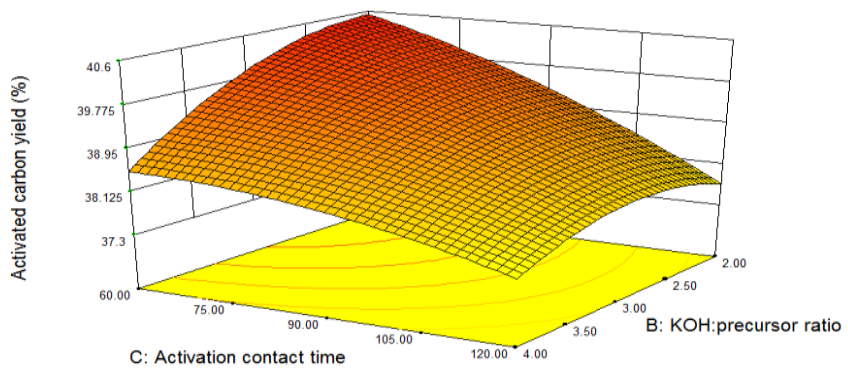

Figure 7 Interaction impact of activation contact time and $\mathrm{KOH}$ to precursor ratio on $\mathrm{Y}(\%)$ at constant activation temperature

\subsection{Validation of the Model}

The values of responses RE (\%) and $Y(\%)$ were maximized to get the optimum operation condition for preparing ACPKS. The preparation ACPKS optimum conditions are: activation temperature of $829.4{ }^{\circ} \mathrm{C}, \mathrm{KOH}$ : precursor ratio of $3.01 \mathrm{w} \%$ and activation contact time of $85 \mathrm{~min}$. The results are listed in Table 6 and found that after repeating the experimental work three times, the predict values was very close to experimental work. It has the percentage error less than (6\%). Thus, the model equation proposed by RSM is valid and could be utilized to predict the responses factors RE and yield accurately.

Table 6 Model validation

\begin{tabular}{l|ll|l|l|l|l|l}
\hline Variables & \multicolumn{9}{c}{ Theoretical } & Experimental \\
\hline $\begin{array}{l}\text { A:Activation } \\
\text { temperature } \\
\text { (C) }\end{array}$ & $\begin{array}{l}\text { B: KOH to } \\
\text { precursor ratio }\end{array}$ & $\begin{array}{l}\text { C: Activation } \\
\text { contact time (min) }\end{array}$ & RE (\%) & Yield (\%) & RE (\%) & Yield (\%) \\
\hline 829.4 & 3.01 & 85 & 94.41 & 39.4 & 96 & 41.2 \\
\hline
\end{tabular}

\subsection{CONCLUSIONS}

In this study, preparation of activated carbon from palm kernel shell was optimized using central composite design. It was implemented to investigate the impact of activation temperature, impregnation ratio of potassium hydroxide $(\mathrm{KOH})$ to precursor and activation time on the thermal activation process of palm kernel shell. Palm kernel shell is demonstrated to be effective for preparing activated carbon for the removal of $\mathrm{H}_{2} \mathrm{~S}$ from an aqueous solution. The results of the optimum preparation conditions for the ACPKS were found to be: activation temperature of $829.4^{\circ} \mathrm{C}$ with $\mathrm{KOH}$ to precursor ratio of $3.01 \mathrm{w} \%$ and activation time of $85 \mathrm{~min}$ with responses of RE and yield of $94.41 \%$ and $39.4 \%$ respectively. The batch mode was utilized for studying adsorption process. The result found that the ACPKS could be the promising adsorbent for removing $\mathrm{H}_{2} \mathrm{~S}$ from wastewater.

\section{Acknowledgement}

This work was funded by Faculty of Chemical \& Natural Resources Engineering, University Malaysia Pahang through a local research grant scheme.

\section{References}

[1] Lambert, T. W., Goodwin, V. M., Stefani, D. 2006. Strosher L. Hydrogen Sulfide $\left(\mathrm{H}_{2} \mathrm{~S}\right)$ and Sour Gas Effects on the Eye. A Historical Perspective. Sci Total Environ. 367: 1-22.

[2] ATSDR. 2008. Minimal Risk Levels (MRLs) for Hazardous Substances. Agency for Toxic Substances and Disease Registry.URL: http://www.atsdr.cdc.gov/mrls/.

[3] EPA. 2003. Toxicological Review of Hydrogen Sulfide. URL: www.epa.gov/iris.
[4] Guidotti, T. L. 1994. Occupational Exposure to Hydrogen Sulfide in the Sour Gas Industry: Some Unresolved Issues. Int Arch Occup Environ Health. 66: 153-160.

[5] Hendrickson, R. G., Chang, A., Hamilton, R. J. 2004. Coworker Fatalities from Hydrogen Sulfide. Am J Ind Med. 45: 346-350.

[6] Heinonen, A. 2012. Adsorption of Hydrogen Sulfide by Modified Cellulose Nano/microcrystals.

[7] Ozekmekci, M., Salkic, G., Fellah, M. F. 2015. Use of Zeolites for the Removal of $\mathrm{H}_{2} \mathrm{~S}$ : A Mini-review. Fuel Process Technol. 139: 49-60.

[8] Chen, Q., Wang, J., Liu, X., Li, Z., Qiao, W., Long, D. 2011. Structure-dependent Catalytic Oxidation of $\mathrm{H}_{2} \mathrm{~S}$ over $\mathrm{Na}_{2} \mathrm{CO}_{3}$ Impregnated Carbon Aerogels. Microporous Mesoporous Mater.142: 641-648.

[9] Chang Y-J, Chang Y-T, Chen H-J. 2007. A Method for Controlling Hydrogen Sulfide in Water by Adding Solid Phase Oxygen. Bioresour Technol. 98: 478-483.

[10] Altaş L, Büyükgüngör H. 2008. Sulfide Removal in Petroleum Refinery Wastewater by Chemical Precipitation. J Hazard Mater. 153: 462-469.

[11] Rehman, Z. U., Farooqi, I. H., Ayub, S. 2010. Performance of Biofilter for the Removal of Hydrogen Sulphide Odour. Int $J$ Environ Res. 3: 537-544.

[12] Dutta, P. K., Rabaey, K., Yuan, Z., Rozendal, R. A. R. A. Keller, J. J. 2010. Electrochemical Sulfide Removal and Recovery from Paper Mill Anaerobic Treatment Effluent. Water Res. 44: 2563-2571.

[13] Sakanishi, K., Wu, Z., Matsumura, A., Saito, I., Hanaoka, T., Minowa, T. 2005. Simultaneous Removal of $\mathrm{H}_{2} \mathrm{~S}$ and COS using Activated Carbons and Their Supported Catalysts. Catal Today. 104: 94-100.

[14] Lemos, B. R. S. S., Teixeira, I. F., de Mesquita, J. P. J. P., Ribeiro, R. R., Donnici, C. L., Lago, R. M. 2012. Use of Modified Activated Carbon for the Oxidation of Aqueous Sulfide. Carbon. 50: 1386-1393.

[15] Kazmierczak-Razna, J., Gralak-Podemska, B., Nowicki, P. and Pietrzak, R. 2015. The Use of Microwave Radiation for Obtaining Activated Carbons from Sawdust and Their Potential Application in Removal of $\mathrm{NO}_{2}$ and $\mathrm{H}_{2} \mathrm{~S}$. Chemical Engineering Journal. 269: 352-358.

[16] Foo, 5. 5. K. and Hameed, B. H. 2010. Insights into the Modeling of Adsorption Isotherm Systems. Chemical Engineering Journal. 156: 2-10. 
[17] Sanghi, R., Bhattacharya, B. 2002. Review on Decolorisation of Aqueous Dye Solutions by Low Cost Adsorbents. Color Technol. 118: 256-269.

[18] Meshko, V., Markovska, L., Mincheva, M., Rodrigues, A. E. 2001. Adsorption of Basic Dyes on Granular Acivated Carbon and Natural Zeolite. Water Res. 35: 3357-3366.

[19] Weber, W. J., Morris, J. C. 1964. Hydrophobic Surfaces. Pergamon Press, New York.

[20] Subramaniam, R., Kumar Ponnusamy, S. 2015. Novel Adsorbent from Agricultural Waste (Cashew NUT Shell) for Methylene Blue Dye Removal: Optimization by Response Surface Methodology. Water Resour Ind. 11: 64-70.

[21] Zhou, L. 2006. Adsorption: Progress in Fundamental and Application Research: Selected Reports at the 4th Pacific Basin Conference on Adsorption Science and Technology: Tianjin, China. 22-26.

[22] Sigot, L., Ducom, G. and Germain, P. 2016. Adsorption of Hydrogen Sulfide $\left(\mathrm{H}_{2} \mathrm{~S}\right)$ on Zeolite (Z): Retention Mechanism. Chemical Engineering Journal. 287: 47-53.

[23] Belmabkhout, Y., De Weireld, G., Sayari, A. 2009. Aminebearing Mesoporous Silica for $\mathrm{CO}_{2}$ and $\mathrm{H}_{2} \mathrm{~S}$ Removal from Natural Gas and Biogas. Langmuir. 25: 13275-13278.

[24] Bae, J. W., Kang, S-H, Dhar, G. M., Jun, K-W. 2009. Effect of $\mathrm{Al}_{2} \mathrm{O}_{3}$ Content on the Adsorptive properties of $\mathrm{Cu} / \mathrm{ZnO} / \mathrm{Al}_{2} \mathrm{O}_{3}$ for Removal of Odorant Sulfur Compounds. Int J Hydrogen Energy. 34: 8733-8740.

[25] Habeeb, O. A., Ramesh, K., Ali, G. A. M., Yunus, R. M. 2017. Isothermal Modelling Based Experimental Study of Dissolved Hydrogen Sulfide Adsorption From Waste Water Using Eggshell Based Activated Carbon. Malaysian J Anal Sci. 21: 334-345

[26] Dabrowski, A., Podkościelny, P., Hubicki, Z., Barczak, M. 2005. Adsorption of Phenolic Compounds by Activated Carbon--A Critical Review. Chemosphere. 58: 1049-1070.

[27] Ahmed, S., Rasul, M., Martens, W. 2010. Heterogeneous Photocatalytic Degradation of Phenols in Wastewater: A Review on Current Status and Developments. Desalination. 261: 3-18.

[28] Haddadian, Z., Shavandi, M. A., Zainal, Z., Halim, M., Ismail, S. 2013. Removal Methyl Orange from Aqueous Solutions Using Dragon Fruit (Hylocereusundatus) Foliage. Chem Sci Trans. 2: 900-910.

[29] Phooratsamee, W., Hussaro, K., Teekasap, S. and Hirunlabh, J. 2014. Increasing Adsorption of Activated Carbon from Palm Oil Shell for Adsorb $\mathrm{H}_{2} \mathrm{~S}$ from biogas Production by I/mpregnation. American Journal of Environmental Sciences. 10: 431-445.

[30] Shang, G., Li, Q., Liu, L., Chen, P. and Huang, X. 2016. Adsorption of Hydrogen Sulfide by Biochars Derived from Pyrolysis of Different Agricultural/Forestry Wastes. Journal of the Air \& Waste Management Association. 66: 8-16.

[31] Foo, K. Y., Hameed, B. H. 2011. Microwave Assisted Preparation of Activated Carbon from Pomelo Skin for the Removal of Anionic and Cationic Dyes. Chem Eng J. 173: 385-390.

[32] Nowicki, P., Skibiszewska, P., Pietrzak, R. 2013. $\mathrm{NO}_{2}$ Removal on Adsorbents Prepared from Coffee Industry Waste Materials. Adsorpt Int Adsorpt Soc. 19: 521-528.

[33] Misnon, I. I., Zain, N. K. M., Aziz, R. A., Vidyadharan, B. and Jose, R. 2015. Electrochemical Properties of Carbon from Oil Palm Kernel Shell for High Performance Supercapacitors. Electrochimica Acta.174: 78-86.

[34] Sumathi, S., Chai, S. P. and Mohamed, A. R. 2008.
Utilization of Oil Palm as a Source of Renewable Energy in Malaysia. Renewable and Sustainable Energy Reviews. 12: 2404-2421.

[35] Box, G. E. P., Wilson, K. B. 1951. On the Experimental Attainment of Optimum Conditions. J R Stat Soc Ser B. 13: $1-45$.

[36] Hounsa, C. G., Aubry, J. M., Dubourguier, H. C., Hornez, J. P. 1996. Application of Factorial and Doehlert Designs for Optimization of Pectate Lyase Production by a Recombinant Escherichia Coli. Appl Microbiol Biotechnol. 45: 764-70.

[37] Habeeb, O. A., Ramesh, K., Ali, G. A. M., Yunus, R. M. 2017. Optimization of Activated Carbon Synthesis Using Response Surface Methodology to Enhance H2S Removal From Refinery Wastewater. J Chem Engin Indust Biotechnol. 1: 1-17.

[38] Azargohar, R., Dalai, A. K. 2005. Production of Activated Carbon from Luscar Char: Experimental and Modeling Studies. Microporous Mesoporous Mater. 85: 219-25.

[39] Zainudin, N. F., Lee, K. T., Kamaruddin, A. H., Bhatia, S., Mohamed, A. R. 2005. Study of Adsorbent Prepared from Oil Palm Ash (OPA) for Flue Gas Desulfurization. Sep Purif Technol. 45: 50-60.

[40] Hassani, A., Alidokht, L., Khataee, A. R., Karaca, S. 2014. Optimization of Comparative Removal of Two Structurally Different Basic Dyes Using Coal as a Low-cost and Available Adsorbent. J Taiwan Inst Chem Eng. 45: 15971607.

[41] Roy, P., Mondal, N. K., Das, K. 2014. Modeling of the Adsorptive Removal of Arsenic: A Statistical Approach. J Environ Chem Eng. 2: 585-597.

[42] Chaudhary, N., Balomajumder, C. 2014. Optimization Study of Adsorption Parameters for Removal of Phenol on Aluminum Impregnated Fly Ash Using Response Surface Methodology. J Taiwan Inst Chem Eng. 45: 852-859.

[43] Alam, M. Z., Ameem, E. S., Muyibi, S. A., Kabbashi, N. A. 2009. The Factors Affecting the Performance of Activated Carbon Prepared from Oil Palm Empty Fruit Bunches for Adsorption of Phenol. Chem Eng J. 155: 191-198.

[44] Habeeb, O. A., Ramesh, K., Ali, G. A. M., Yunus, R. M. Olalere, O.A. 2016. Modeling and Optimization for $\mathrm{H}_{2} \mathrm{~S}$ Adsorption From Wastewater Using Coconut Shell Based Activated Carbon. Australian J Basic Appl Sci. 10: 136-147.

[45] Basu, J. K., Monal, D., Pinaki, G. 2012. Statistical Optimization for the Prediction of Ibuprofen Adsorption Capacity by Using Microwave Assisted Activated Carbon. Arch Appl Sci Res. 4: 1053-60.

[46] Li, S., Han, K., Li, J., Li, M. and Lu, C. 2017. Preparation and Characterization of Super Activated Carbon Produced from Gulfweed by $\mathrm{KOH}$ Activation. Microporous and Mesoporous Materials. 243: 291-300.

[47] Chowdhury, Z. Z., Zain, S. M., Khan, R. A., Ahmad, A. A. Khalid, K. 2012. Application of response Surface Methodology (RSM) for Optimizing Production Condition for Removal of $\mathrm{Pb}$ (II) and $\mathrm{Cu}$ (II) onto Kenaf Fiber based Activated Carbon. Res J Appl Sci Eng Technol. 4: 458-465.

[48] Habeeb, O. A., Ramesh, K., Ali, G. A. M., Yunus, R. M. 2017. Experimental Design Technique on Removal of Hydrogen Sulfide Using CaO-Eggshells Dispersed onto Palm Kernel Shell Activated Carbon: Experiment, Optimization, Equilibrium and Kinetic Studies. J Wuhan Univ TechnolMater Sci Ed. 32: 305-32. 